Биополимеры растений

УДК 661.185

\title{
ПРИВИТАЯ РАДИКАЛЬНАЯ (СО)ПОЛИМЕРИЗАЦИЯ ВОДОРАСТВОРИМЫХ ПРОИЗВОДНЫХ ЛИГНИНА С МЕТИЛАКРИЛАТОМ
}

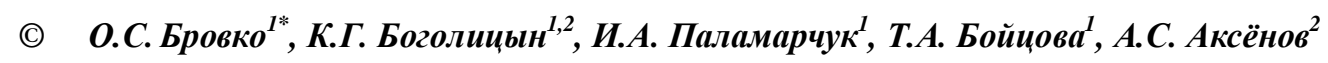

${ }^{1}$ Институт экологических проблем Севера УрО РАН, наб. Северной Двины, 23, Архангельск, 163000 (Россия), e-mail: brovko-olga@rambler.ru

${ }^{2}$ Северный (Арктический) федеральный университет, наб. Северной Двины, 17, Архангельск, 163002 (Россия)

Методом радикальной полимеризации проведен синтез привитых сополимеров лигносульфоната натрия с метилакрилатом. На основе данных ИК-спектроскопии и функционального анализа предложен механизм радикальной привитой сополимеризации. Изучены полиэлектролитные, гидродинамические, полимолекулярные и поверхностноактивные свойства водорастворимых привитых сополимеров.

Ключевые слова: лигносульфонат натрия, метилакрилат, радикальная полимеризация, сополимер.

Работа выполнена при финансовой поддержке проекта РФФИ-Север (11-03-98803 а), ФЦП «Научные и научно-педагогические кадры инновачионной России» на 2009-2013 годы (ГК № 16.740.11.0159) и междисииплинарного проекта УрО РАН (№12-М-45-2012) на оборудовании Центра коллективного пользования научным оборудованием «Критические технологии РФ в области экологической безопасности Арктики» (ИЭПС, ИФПА УрО РАН).

\section{Введение}

Полифункциональная природа лигнинов открывает широкие перспективы их использования для создания полимерных комплексов, на основе которых возможно получение разделительных мембран, нано- и микрокапсул, сорбентов, матриц для иммобилизации ферментов и т.д. Полученные таким образом материалы находят применение в биотехнологии, технике, медицине, для целей эколого-аналитического контроля окружающей среды. Для использования лигнинов в разнообразных областях часто требуется придать им новые свойства. Химическая модификация приводит к функционализации лигнинной макро-

Бровко Ольга Степановна - старший научный сотрудник, кандидат химических наук, тел.: (8182) 28-70-06, e-mail: brovko-olga@ rambler.ru Боголицын Константин Григорьевич - директор Института экологических проблем, проректор по научной работе Северного (Арктического) федерального университета, тел.: (8182) 28-76-06, e-mail: bogolitsyn@iepn.ru, bogolitsyn@agtu.ru

Паламарчук Ирина Анатольевна - старший научный сотрудник, кандидат химических наук, тел.: (8182) 28-55-40, e-mail: Irpalamarchuk@mail.ru Бойцова Татьяна Александровна - старший научный сотрудник, тел.: (8182) 28-55-40,

e-mail: t.boitsova@yandex.ru

Аксенов Андрей Сергеевич - доцент, кандидат технических наук, e-mail: aaksjonov@ yandex.ru молекулы, позволяет ввести в структуру лигнина новые реакционно-способные группы и тем самым способствует получению на основе модифицированного лигнина материалов с улучшенными потребительскими свойствами. Перспективным в этом плане выглядит метод привитой радикальной полимеризации с применением мономера акрилового ряда - метилакрилата, хорошо зарекомендовавшего себя в реакциях такого типа.

Исследования подобного плана [1-3], выполненные в 70-80-х гг. ХХ в., носят единичный характер, однако позволяют оценить перспективность выбранного направления модификации лигнина, о чем

\footnotetext{
* Автор, с которым следует вести переписку.
} 
свидетельствует также возрождение интереса к обсуждаемой проблеме в последние годы [4, 5]. При этом обсуждаемые работы детально не раскрывают механизма сополимеризации, без внимания остались также физико-химические свойства синтезированных сополимеров, определяющие области их практического использования.

Таким образом, целью исследования являлось изучение механизма привитой сополимеризации водорастворимых сульфопроизводных лигнина и метилакрилата и оценка физико-химических свойств полученных привитых сополимеров.

\section{Экспериментальная часть}

Объекты исследования. Технические лигносульфонаты натрия (ЛСNa), полученные в результате сульфитной делигнификации древесины ели на ОАО «Группа «Илим» в г. Коряжме, ТУ 13-0281036-029-94. Лигносульфоновая кислота (ЛСН), полученная путем перевода образца ЛСNa в $\mathrm{H}^{+}$форму на колонке с катионитом КУ-2-8. Метилакрилат (МА), ООО «ВитаРеактив», Нижегородская обл., г. Дзержинск, ТУ 2435003-52470063-2003.

Meтоды исследования. Ультрафильтрацию лигносульфонатов с применением полисульфоновой мембраны ПС-70 проводили на лабораторной установке типа ФМ 02-1000 с перемешиванием.

Молекулярную массу ЛСNа и водорастворимых привитых сополимеров определяли методом гельпроникающей хроматографии на колонке с гелем Сефадекс G-75. В качестве элюента использовали буферный раствор с рН 6,2 (состав буфера: $1 \mathrm{M} \mathrm{NaCl}+0,0546 \mathrm{M} \mathrm{Na}_{2} \mathrm{PO}_{4}+0,018 \mathrm{M} \mathrm{NaOH}$ ) [6].

Определение содержания функциональных групп в ЛСNa и сополимерах проводили по стандартным методикам согласно [7].

Потенциометрические измерения выполняли на $\mathrm{pH}$-метре 211 производства Hanna instruments c комбинированным стеклянным электродом HI 1131 в в качестве измерительного.

Содержание лигносульфонатов в растворе определяли спектральным методом на спектрофотометре UV1800 («Shimadzu», Япония). ИК-спектры твердых образцов в виде таблеток в бромиде калия регистрировали на

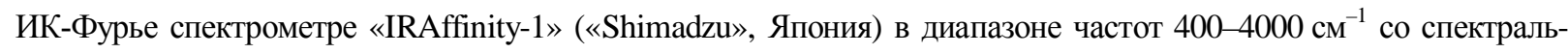
ным разрешением $4 \mathrm{~cm}^{-1}$ и числом сканирований 30 . Концентрация образца в $\mathrm{KBr}$ составляла 1 масс. \%.

Вязкость водных растворов полимеров измеряли с помощью вискозиметра Оствальда с диаметром капилляра 0,56 мм при температуре $25 \pm 0,1{ }^{\circ} \mathrm{C}$. Поверхностное натяжение растворов полимеров определяли

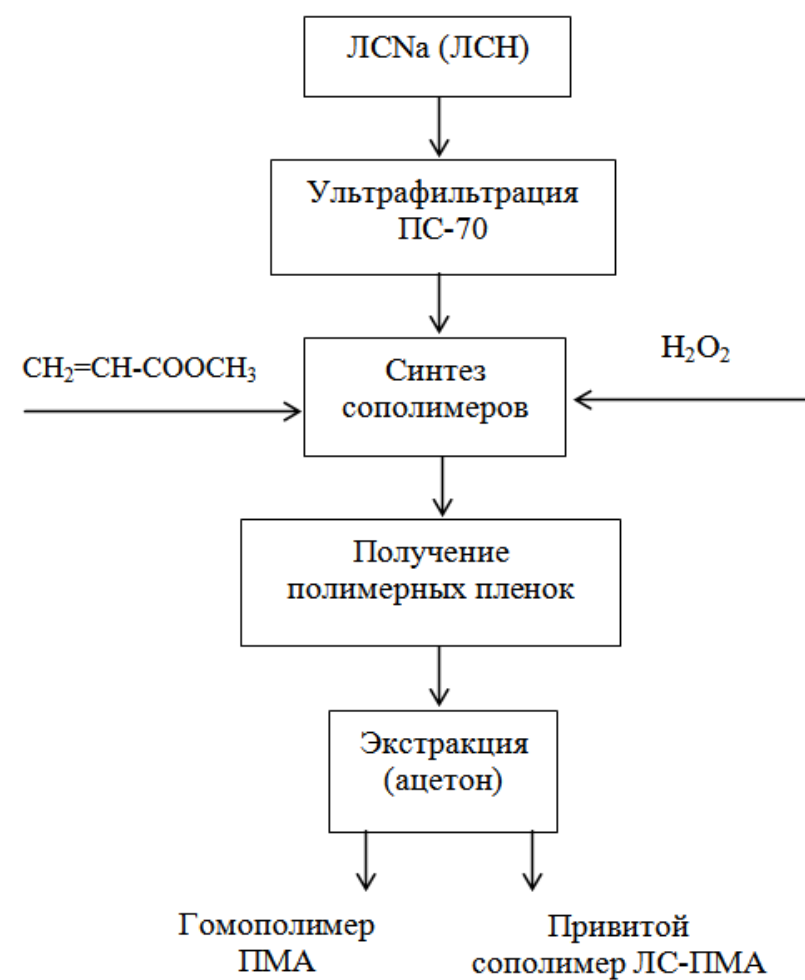

Рис. 1. Схема синтеза привитых сополимеров сульфированных лигнинов с метилакрилатом методом тензиометрии (метод Вильгельми по отрыву пластинки от границы раздела фаз) при температуре $22,0 \pm 0,5^{\circ} \mathrm{C}$.

Синтез привитых сополимеров сульфированных лигнинов с метилакрилатом проводили в реакторе, снабженном механической мешалкой, термометром и обратным холодильником. В реактор помещали расчетное количество водного раствора ЛСNa (ЛСН), очищенного от низкомолекулярных примесей методом ультрафильтрации. Затем в реактор добавляли МА при различных мольных соотношениях реагирующих компонентов (Z). В процессе синтеза также варьировалось количество вводимого в систему инициатора - пероксида водорода. Синтез проводили при температуре 95$97{ }^{\circ} \mathrm{C}$ до полной конверсии МА. В результате реакции сополимеризации образуются водные дисперсии, методом полива которых на подложку получали полимерные пленки. Затем проводили экстракцию полиметилакрилата (ПМА) из пленок ацетоном на аппарате Сокслета в течение 70 ч. Условия проведения синтеза подобраны на основании ранее выполненных исследований [1-5]. Схема процесса синтеза приведена на рисунке 1. 
Состав реакционной смеси $\mathrm{Z}$ в процессе синтеза рассчитывали по формуле:

$$
Z=\frac{C_{M A}^{C M}}{C_{\pi C N a}^{C M}}
$$

где $C_{M A}^{C M}$ - концентрация МА в смеси, моль ${ }^{-1}$; а $C_{Л C N a}^{C M}-$ концентрация ЛСNа в реакционной смеси, рассчитанная с учетом его грамм-эквивалента [8].

\section{Обсуждение результатов}

На рисунке 2 показана зависимость эффективности прививки (ЭП) и степени прививки (СП) метилакрилата на лигносульфонат от состава реакционной смеси $\mathrm{Z}$ в процессе синтеза. Эффективность прививки показывает отношение количества мономера (МА), вошедшего в привитой сополимер, к количеству мономера, образовавшего гомополимер - ПМА. Степень прививки определяется отношением количества МА, вошедшего в привитой сополимер, к массе исходного ЛСNa.

Увеличение Z приводит к росту степени прививки MA на ЛCNa, что обусловлено повышением концентрации мономера в системе, при этом невысокая эффективность процесса, не превышающая 55\% при практически 100\%-ной конверсии мономера, объясняется протеканием в системе наряду с сополимеризацией процесса гомополимеризации МА. Снижение ЭП при невысоких концентрациях акрилового мономера в системе $(Z \leq 5,6)$, вероятно, связано с большей миграционной способностью небольших молекул мономера по сравнению с крупными макромолекулами ЛСNa, в результате чего преобладают столкновения олигомерных акриловых радикалов с мономером с образованием гомополимера. Продукт синтеза во всех случаях представляет собой смесь гомополимера ПМА и привитого сополимера ЛСNa - ПМА. Это стабильные водные дисперсии, которые легко разбавляются водой и не коагулируют при добавлении разбавленных кислот и щелочей, таким образом, привитой сополимер играет в подобных системах роль эффективного стабилизатора частиц ПМА. До соотношения $\mathrm{Z}=2$ в процессе синтеза образуются водорастворимые сополимеры, дальнейшее увеличение количества вводимого в реакционную смесь МА приводит к образованию частично растворимых и далее нерастворимых в воде сополимеров.

Результаты, представленные в таблице 1, показывают, что с увеличением мольного соотношения компонентов в реакционной смеси в процессе синтеза удается получить сополимер с большей молекулярной массой. Аналогичный эффект может быть достигнут и при увеличении вводимого в систему инициатора при одинаковом Z.

При этом следует отметить, что изменение среднемассовой молекулярной массы водорастворимых сополимеров при увеличении вводимого в систему МА при обоих расходах инициатора $(0,04$ и 0,1 г/г) носит линейный характер (рис. 3), что позволяет прогнозировать величину молекулярных масс получаемых сополимеров при изменении условий их синтеза.

Модификация лигносульфоната МА приводит к увеличению степени полидисперсности сополимера (n) в сравнении с исходным ЛCNa, причем с увеличением расхода инициатора в процессе синтеза степень полидисперсности полученных сополимеров возрастает (табл. 1).
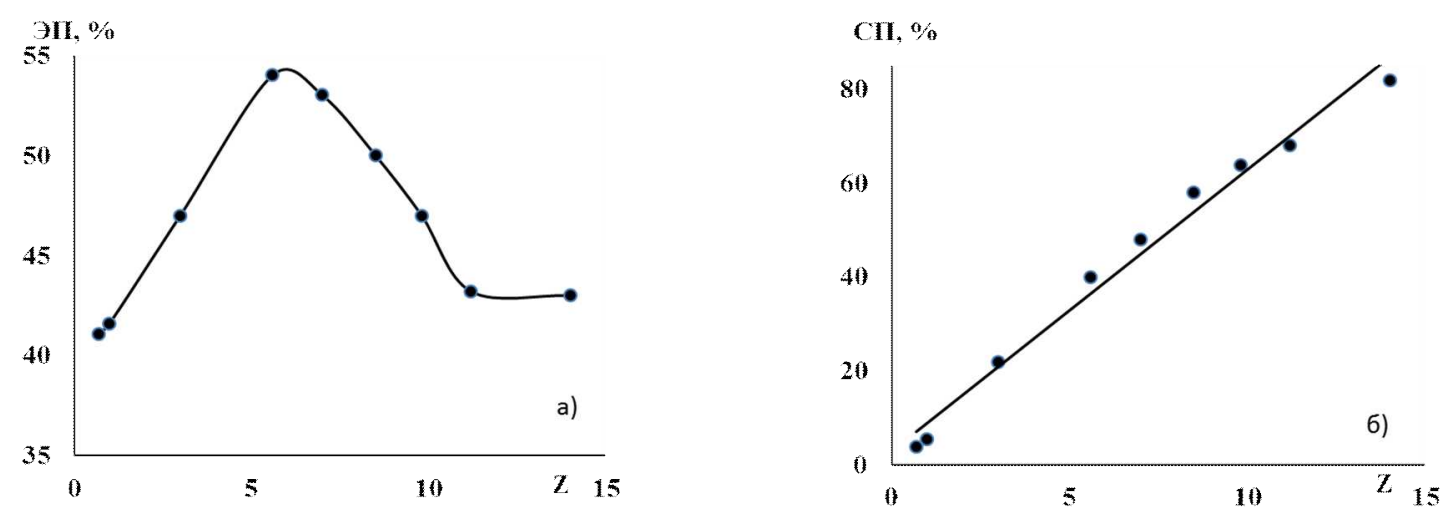

Рис. 2. Зависимость эффективности (а) и степени прививки (б) МА на ЛСNa от состава реакционной смеси Z 
Таблица 1. Условия синтеза и молекулярно-массовые характеристики ЛСNa и сополимеров ЛСNa-ПМА

\begin{tabular}{|c|c|c|c|c|c|c|}
\hline \multirow{2}{*}{ № } & \multirow{2}{*}{ Образец } & \multirow{2}{*}{$\mathrm{Z}$} & \multirow{2}{*}{ Расход $\mathrm{H}_{2} \mathrm{O}_{2}, \Gamma / \Gamma$ ЛCNa } & $\mathrm{M}_{\mathrm{n}}$ & $\mathrm{M}_{\mathrm{w}}$ & \multirow{2}{*}{$n=\frac{M_{w}}{M_{n}}$} \\
\hline & & & & \multicolumn{2}{|c|}{ кДа } & \\
\hline 1 & ЛCNa & - & - & 5,4 & 24,0 & 4,25 \\
\hline 2 & ЛСNa-ПМА & 1 & 0,04 & 8,9 & 50,2 & 5,64 \\
\hline 3 & ЛСNa-ПМА & 1,4 & & 9,9 & 51,2 & 5,15 \\
\hline 4 & ЛСNa-ПМА & 2 & & 12,6 & 63,4 & 5,01 \\
\hline 5 & ЛСNa-ПМА & 1 & 0,1 & 7,4 & 50,7 & 6,83 \\
\hline 6 & ЛСNa-ПМА & 1,4 & & 8,8 & 55,0 & 6,25 \\
\hline 7 & ЛСNa-ПМА & 2 & & 10,2 & 66,6 & 6,49 \\
\hline
\end{tabular}

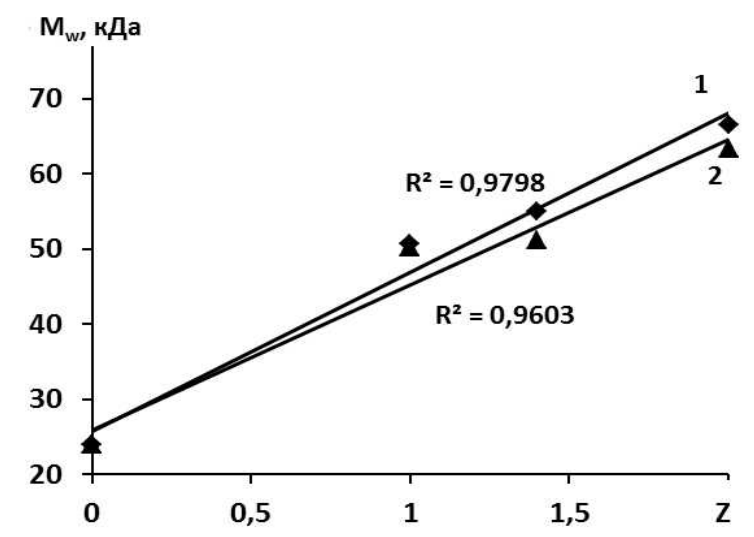

Рис. 3. Зависимость среднемассовой молекулярной массы сополимеров ЛСNa-ПМА от $\mathrm{Z}$ при расходе инициатора: $1-0,1$ и $2-0,04$ г/г ЛСNa

На рисунке 4 приведены колебательные ИК-спектры ЛСNa и типичный спектр одного из привитых сополимеров ЛCNa - ПМА (Z=7), в таблице 2 показаны отнесения полос в спектрах. Полосы поглощения, обусловленные скелетными колебаниями ароматического кольца, проявляются в спектре при 1602, 1510, 1420-1450 см${ }^{-1}$, валентным колебаниям сульфогрупп соответствуют полосы при 1210 и $1039 \mathrm{~cm}^{-1}$. Интенсивность полосы поглощения карбонильных групп ЛСNa при $1715 \mathrm{~cm}^{-1}$ незначительна (рис. 4, табл. 2). В целом колебательные спектры привитого сополимера и лигносульфоната имеют сходный рисунок, однако в спектре сополимера присутствует плечо (полоса) в области $1660 \mathrm{~cm}^{-1}$, характерное для сопряженных кетонных карбонилов и возникающее при батохромном сдвиге полосы при $1715 \mathrm{~cm}^{-1}$, обусловленном сопряжением с ароматическим кольцом. Кроме того, в спектре сополимера появляется новая полоса поглощения при 1730-1735 $\mathrm{cm}^{-1}$, соответствующая валентным колебаниям связи $-\mathrm{C}=\mathrm{O}$ в сложных эфирах. При росте доли МА в реакционной смеси при синтезе сополимера наблюдается значительное увеличение относительной оптической плотности полос в спектрах сополимеров при 1730-1735 и $1166 \mathrm{~cm}^{-1}$, обусловленных поглощением карбонильных групп и эфирных связей сложноэфирных группировок, входящих в состав ПМА.

Содержание основных функциональных групп в лигносульфонатах и синтезированном привитом сополимере ЛСNa - ПМА (Z=1) приведено в таблице 3 .

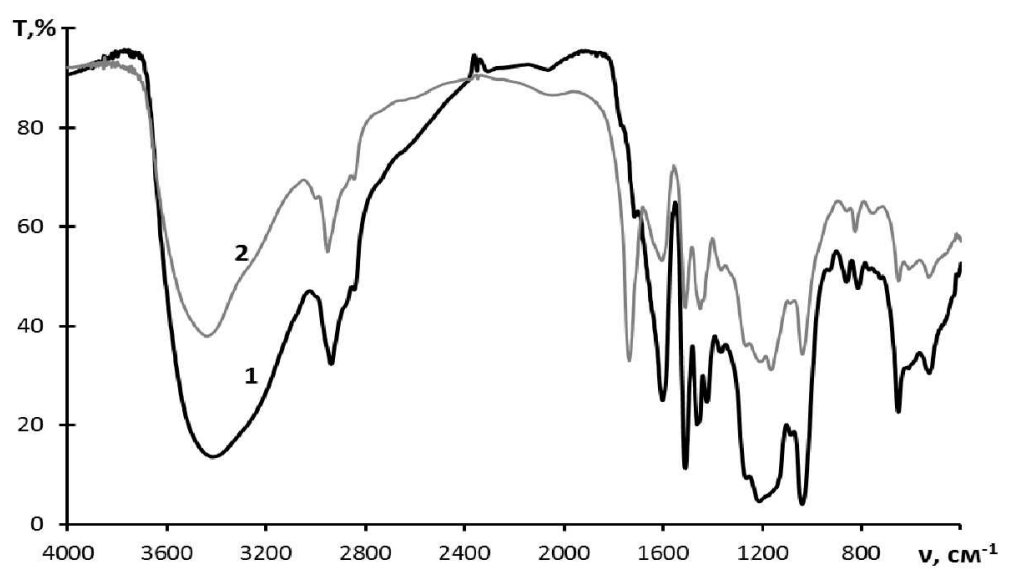

Рис. 4. ИК-спектры ЛСNa (1); привитого сополимера ЛСNa - ПМА, Z=7 (2) 
Таблица 2. Отнесение колебаний в ИК-спектрах лигносульфоната натрия и привитых сополимерах ЛСNa ПМА [9]

\begin{tabular}{|c|c|}
\hline Волновое число, $\mathrm{cm}^{-1}$ & Тип колебания, интенсивность, примечание \\
\hline $\begin{array}{c}3415 \\
2941 \\
1730-1735 \\
1715 \\
1660 \\
1603,1508,1420-1450 \\
1460 \\
1422-1430 \\
1365 \\
1205-1210 \\
1265,1085 \\
1166 \\
1039 \\
860\end{array}$ & $\begin{array}{c}v(\mathrm{O}-\mathrm{H}), \text { с., шир. (вовлеченные в водородную связь ОН группы }) \\
v(\mathrm{C}-\mathrm{H}), \text { ср., асим. в метильных и метиленовых группах } \\
v(\mathrm{C}=\mathrm{O}), \text { с., в сложных эфирах } \\
v(\mathrm{C}=\mathrm{O}) \text { в альдегидах, несопряженных кетонах и СООН-группах } \\
v(\mathrm{C}=\mathrm{O}), \text { оч. сл., в сопряженных кетонах } \\
\text { скелетные колебания ароматических С-С связей } \\
\delta(\mathrm{C}-\mathrm{H}) \text { в метильных и метиленовых группах } \\
v(\mathrm{C}-\mathrm{C}) \text { ароматические скелетные колебания комбинированные, с. } \\
\delta(\mathrm{C}-\mathrm{H}) \text { в метоксильных группах } \\
\delta(\mathrm{C}-\mathrm{H}) \text { при } s p^{3} \text { - гибридизации } \\
v(\mathrm{~S}=\mathrm{O}), \text { сим., ср. } \\
\delta(\mathrm{C}=\mathrm{O}), \text { с., в сложных эфирах } \\
v(\mathrm{C}-\mathrm{O}) \text { в сложных эфирах } \\
v(\mathrm{~S}=\mathrm{O}), \text { сим., с. } \\
\text { внеплоскостные } \delta(\mathrm{C}-\mathrm{H}), \text { сл. в вроматическом кольце }\end{array}$ \\
\hline
\end{tabular}

Таблица 3. Функциональный состав ЛСNa и сополимера ЛСNa - ПМА (в \% к а.с.в.)

\begin{tabular}{c|c|c|c}
\hline \multirow{2}{*}{ Функциональная группа } & \multicolumn{2}{|c}{ Образец } & \multirow{2}{*}{$\Delta, \%$} \\
\cline { 2 - 3 } & ЛСNa & ЛСNa- ПМА (Z=1) & 48,4 \\
\hline$-\mathrm{OH}_{\text {общ. }}$ & $6,2 \pm 0,4$ & $9,2 \pm 0,2$ & 59,6 \\
$-\mathrm{COOH}$ & $1,04 \pm 0,02$ & $1,66 \pm 0,01$ & $-4,5$ \\
$-\mathrm{HSO}_{3}$ & $13,4 \pm 0,3$ & $12,8 \pm 0,4$ & \\
\hline
\end{tabular}

Примечание. $\Delta$ - относительный прирост содержания функциональной группы в образце сополимера в сравнении с ЛCNa, \%

Вследствие сложности процесса сополимеризации, гетерогенности полимеризационной системы, нерегулярности строения водорастворимых сульфопроизводных лигнина к настоящему времени не сложились единые представления о механизме радикальной прививки мономеров к производным лигнина, несмотря на значительный интерес исследователей к этому вопросу. На основе результатов ИКспектроскопии и функционального анализа предложен возможный механизм сополимеризации.

Процесс инициирования характеризуется последовательными реакциями: разложение инициатора (пероксида водорода) с образованием свободных гидроксильных радикалов и дальнейшее их взаимодействие с субстратом (метилакрилатом) с образованием активного центра свободнорадикального типа по реакции 1.

$$
\begin{aligned}
& \mathrm{CH}_{2}=\mathrm{CH}-\mathrm{COOCH}_{3}+\dot{\mathrm{O}} \mathrm{H} \longrightarrow \dot{\mathrm{C}} \mathrm{H}_{2}-\mathrm{CH}-\mathrm{COOCH}_{3} \\
& \mathrm{OH}
\end{aligned}
$$

Далее возможен процесс гомополимеризации МА и наращивание полимерной цепи с образованием в дальнейшем ПМА:

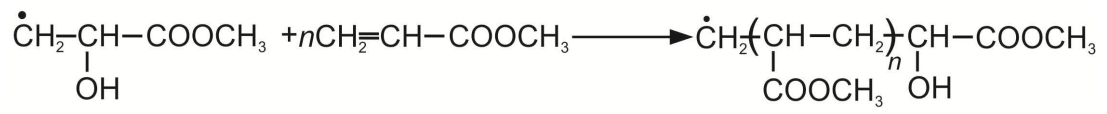

Прививка на макромолекулу сульфированного лигнина может осуществляться за счет обрыва цепи реакционным центром в $о$-положении к фенольному гидроксилу ( $м$-положения пространственно затруднены) по схеме 3:<smiles>[R]c1cc(C(C)S(=O)(=O)O)cc(OC)c1O</smiles> 
Предложенный механизм не предполагает отрыва гидроксильным радикалом атома водорода от фенольного гидроксила, как показано в работе [2], поскольку в этом случае невозможно объяснить рост содержания гидроксильных групп в сополимере (табл. 3), обусловленный вхождением гидроксила в каждый привитый олигомерный радикал, согласно схеме 3.

Безусловно, возможно участие в реакции привитой сополимеризации алифатических двойных связей пропановой цепочки ЛСNa (ЛСН) согласно схеме 4, однако стерический фактор и степень сопряженности связей могут существенно затруднять прививку такого типа.

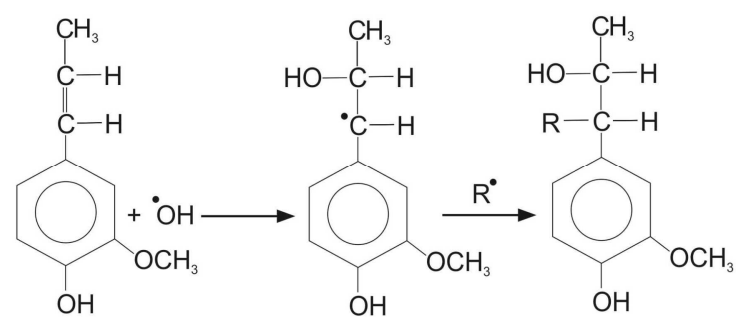

где

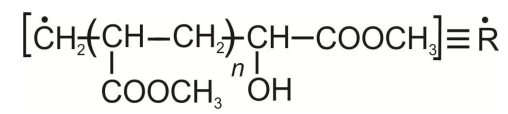

Кроме того, фрагментов с двойной связью в макромолекуле ЛСNa (ЛСН) имеется незначительное количество (около 0,1 на фенилпропановую единицу [10]), о чем также свидетельствует низкая интенсивность полосы (плечо) в ИК-спектре в области 988-960 см ${ }^{-1}$, отвечающей за деформационные колебания связи С-Н при двойной связи. Таким образом, вклад данной реакции в процесс сополимеризации невелик.

Предложенный механизм согласуется с зависимостью растворимости в воде полимерных пленок после экстракции гомополимера от доли метилакрилата в реакционной смеси $(\mathrm{Z})$. При высокой доле МА пленки практически нерастворимы или растворимы в воде лишь частично, что свидетельствует о достаточно большой длине привитых цепочек синтетического полимера, причем на каждую цепочку приходится всего одна гидрофильная гидроксильная группа. При низкой концентрации мономера в смеси длина привитых цепочек в сополимере уменьшается, а количество их в расчете на макромолекулу лигносульфоната возрастает. Такие сополимеры хорошо растворимы в воде, что связано с увеличением числа гидроксильных групп в их макромолекулах (табл. 3).

Методом потенциометрического титрования показано, что в привитом сополимере присутствует большее количество кислых групп, чем в ЛСН, что согласуется с данными, представленными в таблице 3.

Увеличение доли карбоксильных групп в привитом сополимере, вероятно, связано с частичным гидролизом сложноэфирных групп МА в процессе синтеза сополимера. На дифференциальной кривой потенциометрического титрования (рис. 5) для ЛСН и ее сополимера пик, соответствующий точке эквивалентности, наблюдается при объемах титранта 1,1 и 2,3 мл соответственно. Расчетные величины рК кислых групп в исследуемых полиэлектролитах близки, что свидетельствует о схожих протолитических свойствах ЛСН и привитого сополимера ЛСН - МА. Учитывая, что в ходе реакции сополимеризации содержание сульфогрупп в лигнинном полимере существенно не изменяется, а содержание других ионогенных групп (общих гидроксильных и карбоксильных) в продукте синтеза возрастает (табл. 3), то привитой сополимер имеет более выраженный полиэлектролитный характер.

Экспериментально установлена аномальная концентрационная зависимость приведенной вязкости, характерная для полиэлектролитов, для водных растворов ЛСNa и привитого сополимера ЛСNa-ПМА. Наличие ярко выраженного эффекта полиэлектролитного набухания проявляется в возрастании приведенной вязкости при разбавлении раствора полиэлектролита. Разбавление раствора приводит к уменьшению степени экранирования заряда полииона. В результате электростатическое отталкивание одноименно заряженных звеньев цепи увеличивается, что приводит к разворачиванию цепи, увеличению размеров макромолекулярных клубков и повышению приведенной вязкости растворов (рис. 6). Кривая приведенной вязкости раствора сополимера ЛСNa-ПМА (образец 5, табл. 1) лежит выше аналогичной кривой для ЛСNa, что связано, очевидно, с увеличением содержания объемных заместителей (олигомерных цепочек ПМА) и молекулярной массы сополимера (табл. 1) в сравнении с ЛСNa, что приводит к возрастанию гидродинамического объема макромолекулы ЛСNa-ПМА и характеристической вязкости. Характер зависимости приведенной вязкости от концентрации для раствора сополимера ЛСNa-ПМА (образец 2, табл. 1), по-видимому, обусловлен большей разветвленностью макромолекул этого сополимера. 
Сочетание в макромолекулах полимеров фрагментов с полярными ионогенными гидрофильными группами и неполярного гидрофобного каркаса предопределяет их поверхностную активность. Известно, что процесс формирования адсорбционного слоя на межфазной границе в растворах высокомолекулярных соединений носит кинетический характер. Так как в растворах лигносульфонатов адсорбционное равновесие в поверхностном слое достигается через 5-20 ч, поэтому поверхностное натяжения в водных растворах ЛСNa и ЛСNa-ПМА измеряли через сутки после приготовления растворов. Изотермы поверхностного натяжения, представленные на рисунке 7, показывают, что максимальная депрессия поверхностного натяжения для ЛСNa составляет 31, а для сополимеров ЛСNa-ПМА - $26 \mathrm{MH} \cdot \mathrm{M}^{-1}$, причем эта величина практически не зависит от расхода инициатора в процессе синтеза сополимера. Таким образом, модификация лигносульфоната методом привитой сополимеризации приводит к уменьшению способности ЛСNa снижать поверхностное натяжение. Сополимер ЛСNa-ПМА обладает меньшей поверхностной активностью, чем исходный ЛСNa: $64 \cdot 10^{-3}$ и $140 \cdot 10^{-3}$ Дж·м·кГ ${ }^{-1}$ соответственно, что связано с большей гидрофильностью сополимера, обусловленной введением в макромолекулу дополнительных гидрофильных ионогенных групп и небольшой длиной привитых цепей ПМА.

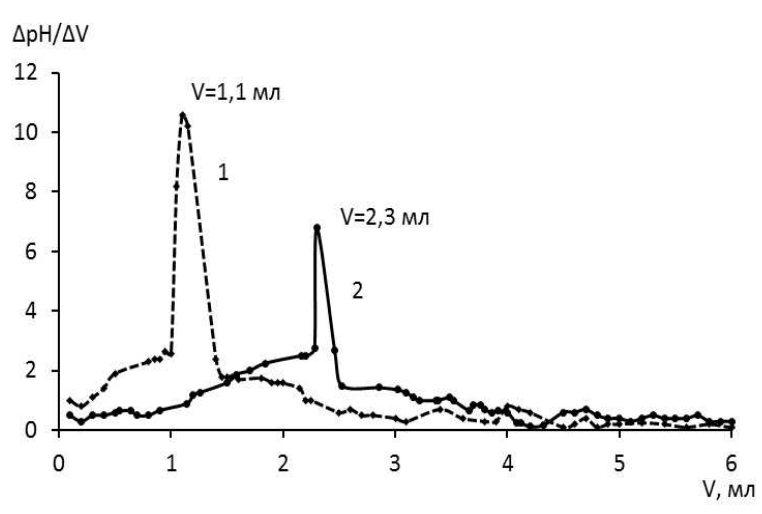

Рис. 5. Дифференциальные кривые потенциометрического титрования водных растворов ЛСН (1); ЛСН - ПМА, Z=1 (2) 0,1 н $\mathrm{NaOH}$

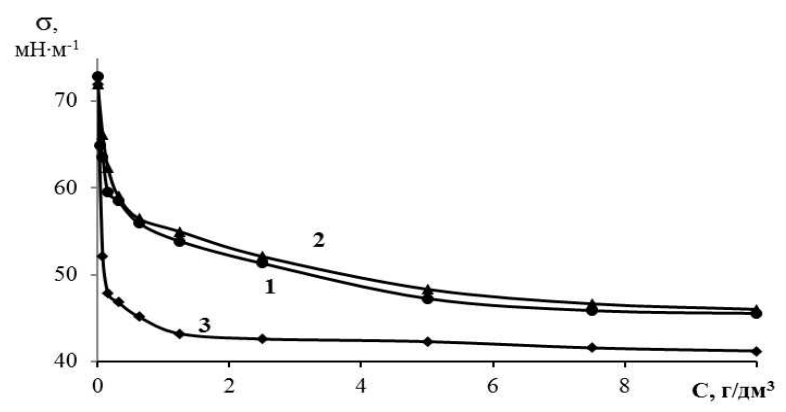

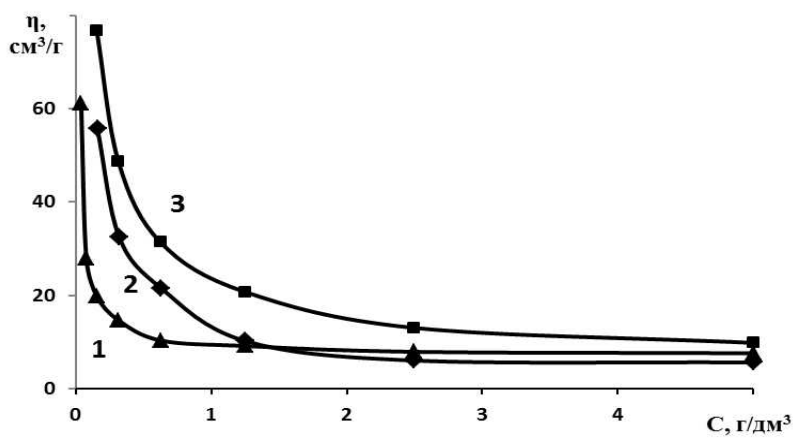

Рис. 6. Концентрационные зависимости приведенной вязкости водных растворов ЛСNa (2) и сополимеров ЛСNa - ПМА при $\mathrm{Z}=1$ : расход инициатора 0,04 (1) и 0,1 (3) г/г ЛCNa
Рис. 7. Изотермы поверхностного натяжения водных растворов ЛСNa (3); и сополимеров ЛСNa - ПМА при Z=1: расход инициатора 0,04 (1) и $0,1(2)$ г/г ЛСNa

\section{Заключение}

Полученные экспериментальные результаты подтверждают корректность предложенного механизма привитой радикальной (со)полимеризации метилакрилата и лигносульфоната натрия в присутствии инициатора (пероксида водорода). Показано, что при соотношении компонентов реакционной смеси $\mathrm{Z} \leq 2$ в процессе синтеза в системе образуются водорастворимые сополимеры, молекулярная масса которых увеличивается в $2,1 \div 2,8$ раза по сравнению с исходным полимером, а поверхностная активность снижается более чем в 2 раза. Установлено, что молекулярная масса сополимеров ЛСNa - ПМА линейно зависит от соотношения компонентов реакционной смеси $(\mathrm{Z})$, что позволяет прогнозировать величину молекулярной массы получаемых водорастворимых сополимеров.

\section{Благодарности}

Авторы благодарят Левандовскую Т.В. и Хабарова Ю.Г. за консультации и обсуждение экспериментальных данныхх. 


\section{Список литературы}

1. Розенберг Л.В., Берлин А.А., Визгерт Р.В. Привитые сополимеры на основе лигносульфоната // Гидролизная и лесохимическая промышленность. 1972. № 5. С. 16-17.

2. Берлин А.А. Химическое модифицирование лигнина путем привитой полимеризации виниловых мономеров (обзор) // Химия древесины. 1982. № 1. С. 3-24.

3. Chen R., Kokta B.V. Graft copolymerization of lignosulfonate with methacrylic acid and acrylate monomers // In Graft Copolymerization Of Lignocellulosic Fibers; Ed. Hon D. ACS Symposium Series; American Chemical Society: Washington, D.C. 1982. Vol. 187. Pp. 285-299.

4. Jian-fa1 L., Zhan-qian S., Shi-bin S., Jin-hong L. Study on graft-copolymerization of grude lignosulfonates with acrylic monomers // Chemistry and Industry of Forest Products 2004. Vol. 24, N3. Pp. 1-6.

5. Mai C., Majcherczyk A., Hüttermann A. Chemo-enzymatic synthesis and characterization of graft copolymers from lignin and acrylic compounds // Enzyme and Microbial Technology. 2000, Vol. 27, N1-2. Pp. 167-175.

6. Соколов О.М. Определение молекулярных масс лигнинов на ультрацентрифуге и методом гель-фильтрации. Л., 1987. $76 \mathrm{c.}$

7. Закис Г.Ф., Можейко Л.Н., Телышева Г.М. Методы определения функциональных групп лигнина. Рига, 1975. $174 \mathrm{c}$.

8. Паламарчук И.А., Бровко О.С., Бойцова Т.А., Вишнякова А.П., Макаревич Н.А. Влияние ионной силы раствора на процесс комплексообразования сульфопроизводных биополимера лигнина и хитозана // Химия растительного сырья. 2011. №2. С. 57-64.

9. Инфракрасная спектроскопия полимеров / под ред. И. Деханта. М., 1976. 472 с.

10. Лигнины (структура, свойства и реакции) / под ред. К.В. Сарканена, К.Х. Людвига. М., 1975. 632 с.

Поступило в редакииио 25 февраля 2013 г.

Brovko O.S. ${ }^{{ }^{*}}$, Bogolitsyn K.G. ${ }^{1,2}$, Palamarchuk I.A. ${ }^{l}$, Boytsova T.A. ${ }^{l}$, Aksyonov A.S. ${ }^{2}$ GRAFTED RADICAL (CO)POLYMERIZATION OF WATER-SOLUBLE LIGNIN DERIVATIVES WITH METHYL ACRYLATE

${ }^{1}$ Institute of Ecological Problems of the North, Ural Branch of Russian Academy of Sciences, Naberezhnaia Severnoi

Dviny, 23, Arkhangelsk, 163000 (Russia),e-mail: brovko-olga@rambler.ru

${ }^{2}$ Northern (Arctic) Federal University named after M.V. Lomonosov, Naberezhnaia Severnoi Dviny, 17, Arkhangelsk, 163002 (Russia)

Grafted radical (co)polymerization of water-soluble lignin derivatives with methyl acrylate was performed. The experimental results confirm the validity of the proposed mechanism of grafted radical (co)polymerization of methyl acrylate and sodium lignosulfonate in the presence of an initiator (hydrogen peroxide). It is shown that for the ratio of the components of the reaction mixture $\mathrm{Z} \leq 2$ in the system water-soluble copolymers are formed, molecular weight increases in $2,1 \div 2,8$ times compared to the base polymer and the surface activity is reduced by more than 2 times. Found that the molecular weight of the copolymers LSNa - PMA is linearly dependent on the ratio of the components of the reaction mixture (Z), which allows to predict the value of the molecular mass for water-soluble copolymers.

Keywords: sodium lignosulfonate, methyl acrylate, radical polymerization, copolymer.

\section{References}

1. Rozenberg L.V., Berlin A.A., Vizgert R.V. Gidroliznaia i lesokhimicheskaia promyshlennost', 1972, no. 5, pp. 16-17. (in Russ.).

2. Berlin A.A. Khimiia drevesiny, 1982, no. 1, pp. 3-24. (in Russ.).

3. Chen R., Kokta B.V. Graft Copolymerization Of Lignocellulosic Fibers. Ed. Hon D. ACS Symposium Series; American Chemical Society: Washington, D.C. 1982, vol. 187, pp. 285-299.

4. Jian-fa1 L., Zhan-qian S., Shi-bin S., Jin-hong L. Chemistry and Industry of Forest Products, 2004, vol. 24, no. 3, pp. 1-6.

5. Mai C., Majcherczyk A., Hüttermann A. Enzyme and Microbial Technology, 2000, vol. 27, no. 1-2, pp. 167-175.

6. Sokolov O.M. Opredelenie molekuliarnykh mass ligninov na ul'tratsentrifuge i metodom gel'-fil'tratsii. [Determination of molecular weight lignin by ultracentrifugation method and gel filtration]. Leningrad, 1987, 76 p. (in Russ.).

7. Zakis G.F., Mozheiko L.N., Telysheva G.M. Metody opredeleniia funktsional'nykh grupp lignina. [Methods for determining functional groups lignin]. Riga, 1975, 174 p. (in Russ.).

8. Palamarchuk I.A., Brovko O.S., Boitsova T.A., Vishniakova A.P., Makarevich N.A. Khimiia rastitel'nogo syr'ia, 2011, no. 2, pp. 57-64. (in Russ.).

9. Infrakrasnaia spektroskopiia polimerov / Pod red. I. Dekhanta. [Infrared spectroscopy of polymers / Ed. I. Dehant]. Moscow, 1976, 472 p. (in Russ.).

10. Ligniny (Struktura, svoistva i reaktsii) / Pod red. K.V. Sarkanena, K.Kh. Liudviga. [Lignins (Structure, properties and reaction) / Ed. K.V. Sarkane, K.H. Ludwig.]. Moscow, 1975, 632 p. (in Russ.).

\footnotetext{
* Corresponding author.
} 